\title{
Primary Lymphoma of the
}

\section{Kidney in an Adult Male - The First Reported Case from Iran}

\author{
Mohammad Kazem Moslemi ${ }^{a}$ Seiied Ali Tahvildara \\ Abdo-Al-Reza Ashtari ${ }^{b}$ \\ Departments of a Urology and ' $P$ athology, Kamkar Hospital, School of Medicine, \\ Qom Medical Sciences University, Qom, Iran
}

\section{Key Words}

Primary renal lymphoma - Chemotherapy · Renal mass · Non-Hodgkin's lymphoma ·

Radical nephrectomy

\section{Abstract}

We report a case of primary renal lymphoma in a 48-year-old man. He was admitted with a large homogenous right renal mass that was revealed by computed tomography scan of the abdomen and pelvis. The patient underwent transperitoneal right radical nephrectomy. Pathologic diagnosis was in favor of primary renal lymphoma.

\section{Introduction}

Renal involvement is common in patients with systemic Non-Hodgkin's lymphoma. Primary renal lymphoma (PRL) is a controversial and rare disease. There is no agreement whether or not it is an initial manifestation or a rapidly systemic disease. The term PRL is applied when the disease is localized to the kidney without any sign of other organ involvement or when renal involvement is the presenting manifestation [1]. Flank pain is the most common presenting symptom, and different histologies have been reported.

\section{Case Presentation}

The patient was a 48-year-old Iranian male who was admitted due to dull abdominal pain, anorexia and fatigue. The pain began 2 months previously. In the past medical history only controlled hypertension was detected. No history of any surgery was present. BMI was 28 . Physical examination showed a palpable mass in the right flank area. Hematological examination results and biochemistry lab data (renal function tests, liver function tests, and other routine lab tests) were within the normal limits, whereas urine analysis showed only microscopic hematuria (10-12 RBCs). An ultrasonographic examination of the abdomen and pelvis showed a large retroperitoneal mass of the right kidney (fig. 2). The contralateral kidney was normal. On the abdominal computed tomography (CT) scan a large 


\begin{tabular}{|c|c|c|c|}
\hline $\begin{array}{l}\text { Cose Reports in } \\
\text { Oncaloy }\end{array}$ & $\begin{array}{l}\text { Case Rep Oncol 2010;3:72-76 } \\
\text { Dol: } 10.1159 / 000298470\end{array}$ & Published online: March 24, 2010 & $\begin{array}{l}\text { (c) } 2010 \text { S. Karger AG, Basel } \\
\text { ISSN } 1662-6575 \\
\text { www.karger.com/cro }\end{array}$ \\
\hline
\end{tabular}

homogenous right renal mass (with $17.5 \times 13 \mathrm{~cm}$ size) was detected. Chest X-ray was within normal limits. Due to suspicion of renal cell carcinoma, transperitoneal right radical nephrectomy with lymphadenectomy was performed (fig. 3 ). The weight of the mass was 3,200 g. Pathologic diagnosis was in favor of Non-Hodgkin's PRL (fig. 2). Bone marrow aspiration was done postoperatively, which was normal. Systemic chemotherapy with 8 courses of CHOPP regimen (cyclophosphamide, adriamycin, vincristine, and prednisone) was initiated without complications. The patient tolerated chemotherapy well and is in good physical condition now, one year after surgery.

\section{Discussion}

Although secondary renal involvement from systemic lymphoma is very frequent, PRL is a rare entity, accounting for only $0.7 \%$ of all extranodal lymphomas [2], and as a clinical entity it is not undisputed because the kidney does not contain lymphatic tissue and the mechanism of development of PRL is unclear [3]. It is characterized by aggressive histopathology, very early extrarenal infiltration and poor prognosis [4]. PRL is defined as a lymphoma that involves only the kidney at presentation and manifests with renal involvement [3]. Diagnosis is established by renal biopsy, although it often presents as a mass simulating renal cell cancer, and diagnosis is obtained after radical nephrectomy [5]. Most PRLs that have been reported were classified as diffuse, large B cell lymphoma, and almost all PRLs were of B cell lineage [6]. PRL is a distinct pathological and clinical entity which is extremely rare and highly aggressive since disseminating rapidly from its origin. Although there are no clearly defined diagnostic criteria for renal lymphomas, abdominal and thoracic $\mathrm{CT}$ as well as renal and bone marrow biopsy are recommended. The disease usually affects adults with an average age of 60 years, and there is a slight male preponderance. Several histogenetic theories of the disease have been postulated since the kidney does not normally contain lymphoid tissue. The neoplastic lymphoid cells may express both $\mathrm{B}$ and $\mathrm{T}$ immunoblastic phenotypes; primary renal Hodgkin's lymphoma has also been reported. The disease may present with progressive renal failure of either oliguric or non-oliguric type. Imaging studies in diagnosing and staging PRL include ultrasound examination and CT scanning. Whole body bone scan and bone marrow biopsy will complete clinical staging of disease. Renal biopsy is important in assessing the diagnosis of PRL. Multidrug chemotherapy is mandatory for high-grade lymphoma and when the disease is diagnosed preoperatively. Survival is extremely poor since $75 \%$ of patients die less than 1 year after operation. Prognosis may be improved by early detection of disease and by performing systemic chemotherapy [7]. One of the differential diagnoses of PRL is mucosa-associated lymphoid tissue (MALT) lymphoma, which is more rare than PRL. MALT lymphoma represents a low-grade B cell marginal zone, the lymphoma arising in extranodal tissue in which lymphoid tissues are usually absent, and it is usually acquired in response to chronic inflammation or in association with an autoimmune disorder. The biological behavior of the disease generally differs from the nodal low-grade B cell lymphoma [8] and responds well to local therapy. In a study by Schniederjan and Osunkoya [9] on the 40 cases of lymphoid neoplasms of the genitourinary tract, the most common site of involvement was the kidney. B cell NonHodgkin's lymphomas predominated, with diffuse large B cell lymphoma being the most common subtype in the entire group. Among renal, bladder, and ureter lymphomas, a male predominance was noted (1.6:1).

Several imaging options exist for evaluation of renal involvement including ultrasonography, intravenous pyelography, CT scan, and magnetic resonance imaging (MRI). Ultrasonography shows renal lymphoma as a hypoechoic mass, a finding that reflects homogeneity. CT scan is the imaging modality of choice for evaluation of the kidneys in patients with suspected renal masses including renal lymphoma [6]. The CT 


\begin{tabular}{|c|c|c|c|}
\hline $\begin{array}{l}\text { Case Reports in } \\
\text { Oncenty }\end{array}$ & $\begin{array}{l}\text { Case Rep Oncol 2010;3:72-76 } \\
\text { D0l: } 10.1159 / 000298470\end{array}$ & Published online: March 24, 2010 & $\begin{array}{l}\text { () } 2010 \text { S. Karger AG, Basel } \\
\text { ISSN } 1662-6575 \\
\text { www.karger.com/cro }\end{array}$ \\
\hline
\end{tabular}

patterns in renal lymphoma include: multiple renal masses (with up to $60 \%$ of the cases), renal invasion from contiguous retroperitoneal disease (seen in $25-30 \%$ of cases), solitary masses (6\% of cases), or diffuse renal infiltration (almost always bilateral and seen in approximately $2 \%$ of patients) [10]. Solid renal masses including renal cell carcinoma and metastases are the most common entities that mimic renal lymphoma at CT [11].

Metastases from primary tumors such as breast cancer, lung cancer, or synchronous renal cell carcinoma often present as bilateral masses that are indistinguishable from multifocal lymphoma, so in such cases, accurate history taking is essential [12]. An infiltrative growth pattern may be seen with tumors such as transitional cell carcinoma or with inflammatory processes such as xanthogranulomatous pyelonephritis.

\section{Conclusion}

PRL represents a rare entity which must nevertheless be considered in cases of unusual renal masses or otherwise unexplained renal symptoms. Based on our knowledge, this is the first case report of PRL from Iran. Standard management of a renal mass is nephrectomy. PRL is a rare exception in which renal biopsy is needed for diagnosis. Chemotherapy is its first-line therapy and consists of a CHOP regimen associated with rituximab. We believe that both the delayed diagnosis and the histological aggressive behavior of the disease are responsible for the poor prognosis of PRL and that if diagnosed early, cure is possible.

Fig. 1. Histologic HE staining of the nephrectomy specimen revealing B cell lymphoma.

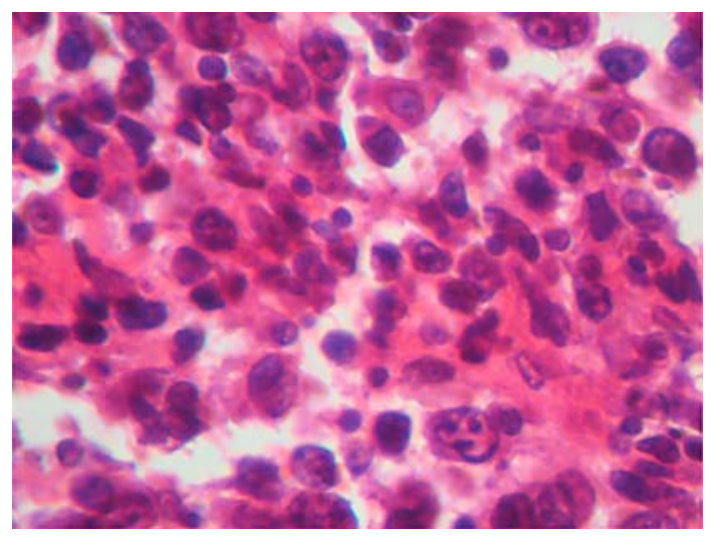




\begin{tabular}{c|l|l|l}
$\begin{array}{c}\text { Cose Reports in } \\
\text { Oncelogy }\end{array}$ & $\begin{array}{l}\text { Case Rep Oncol 2010;3:72-76 } \\
\text { D0l: 10.1159/000298470 }\end{array}$ & & $\begin{array}{l}\text { Published online: March 24, 2010 } \\
\text { ISSN 1662-6575 AG, Basel } \\
\text { www.karger.com/cro }\end{array}$ \\
\hline
\end{tabular}

Fig. 2. Abdominal CT scan revealing a near homogenous mass of the right kidney.

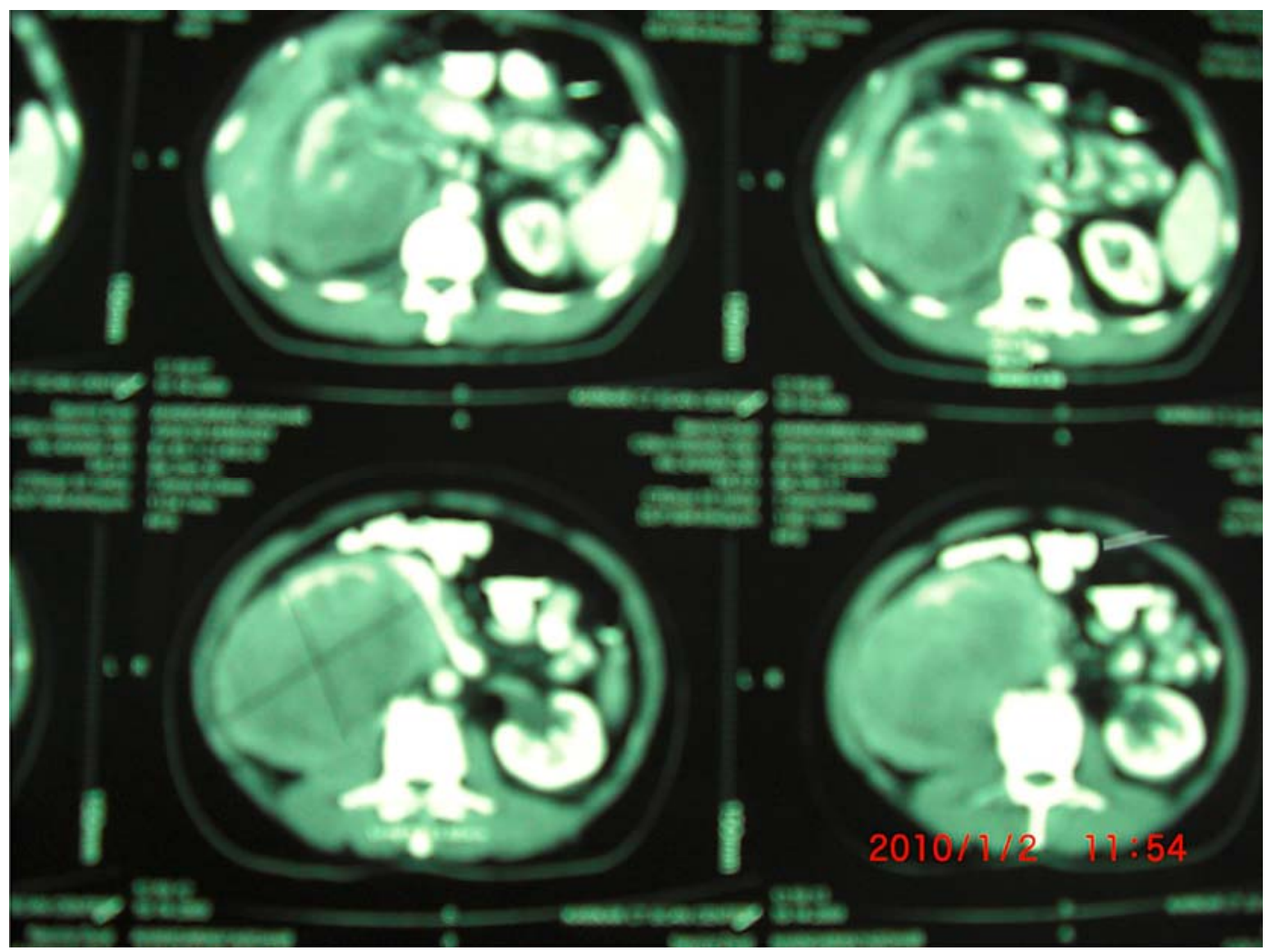

Fig. 3. Abdominal CT scan, two weeks after operation and before systemic chemotherapy, revealing no residual tumor or para-aortic lymph nodes.

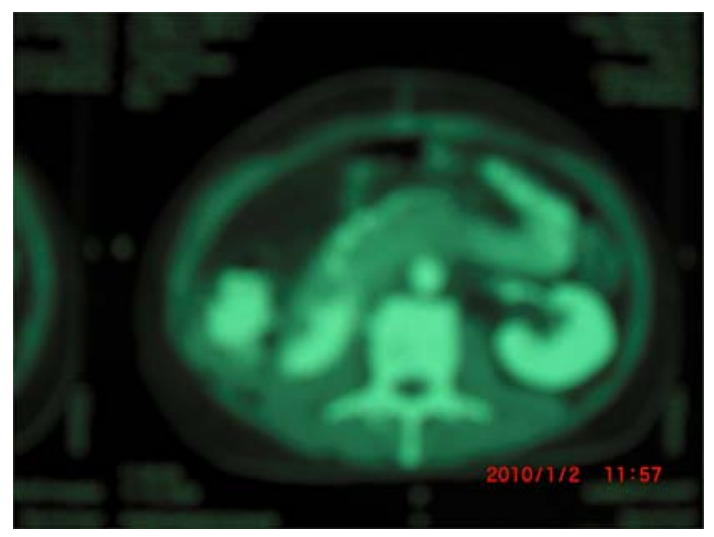




\begin{tabular}{|c|c|c|c|}
\hline $\begin{array}{l}\text { Cose Reports in } \\
\text { inceayly }\end{array}$ & $\begin{array}{l}\text { Case Rep Oncol 2010;3:72-76 } \\
\text { Dol: } 10.1159 / 000298470\end{array}$ & Published online: March 24, 2010 & \begin{tabular}{|l} 
( ) 2010 S. Karger AG, Basel \\
ISSN $1662-6575$ \\
www.karger.com/cro
\end{tabular} \\
\hline
\end{tabular}

\section{References}

-1 Tefekli A, Baykal M, Binbay M, Barut M, Musulmanuglu AY: Lymphoma of the kidney: primary or initial manifestation of rapidly progressive systemic disease? Int Urol Nephrol 2006;38:775-778.

$\checkmark 2$ Freeman C, Berg JW, Culter SJ: Occurrence and prognosis of extranodal lymphomas. Cancer 1972;29:252-260.

-3 Gellrich J, Hakenberg OW, Naumann R, Manseck A, Lossnitz A, Wirth MP. Primary renal non-Hodgkin's lymphoma - a difficult differential diagnosis. Onkologie 2002;25:273-277.

-4 Kose F, Sakalli H, Mertsoylu H, Sezer A, Kocer E, Tokmak N, Killinic F, Ozyilkan O: Primary renal lymphoma: report of four cases. Onkologie 2009;32:200-202.

-5 Vazquez Alonso F, Sanchez Ramos C, Vicente Prados FJ, Pascual Geler M, Ruiz Carazo E, Becerra Massare P, Funes Padilla C, Rodriguez Herrera F, Cozar Olmo JM, Tallada Bunuel M: Primary renal lymphoma: report of three new cases and literature review. Arch Esp Urol 2009;62:461-465.

6 Truong LD, Caraway N, Ngo T, et al: Renal lymphoma: the diagnostic and therapeutic roles of fine-needle aspiration. Am J Clin Pathol 2001;115:18-31.

7 Porcaro AB, DAmico A, Novella G, Curti P, Ficarra V, Antoniolli SZ, Martignoni G, Matteo B, Malossini G: Primary lymphoma of the kidney. Report of a case and update of the literature. Arch Ital Urol Androl 2002;74:44-47.

8 Harris NL, Isaacson PG: What are the criteria for distinguishing MALT from non-MALT lymphoma at extranodal sites. Am J Clin Pathol 1999;111(suppl 1):126-132.

$\checkmark 9$ Schniederjan SD, Osunkoya AO: Lymphoid neoplasms of the urinary tract and male genital organs: a clinicopathological study of 40 cases. Mod Pathol 2009;22:1057-1065.

10 El-Sharkawy MS, Siddiqui N, Aleem A, Diab AA: Renal involvement in lymphoma: prevalence and various patterns of involvement on abdominal CT. Int Urol Nephrol 2007;39:929-933.

11 Mydlo JH, Gerstein M: Patients with urologic cancer and other nonurologic malignancies: analysis of a sample and review of the literature. Urology 2001;58:864-869.

12 Pinggera GM, Peschel R, Buttazzoni A, Mitterberger M, Friedrich A, Pallwein L: A possible case of primary renal lymphoma: a case report. Cases J 2009;2:6233. 